Fecha de recepción: diciembre 2010 Fecha de aceptación: julio 2011 Versión final: marzo 2012

\section{Nuevos modos de exposición y circulación de las imágenes fotográficas}

Mercedes Pombo *

\begin{abstract}
Resumen: Desde las últimas décadas del siglo XX la circulación de fotografías y de obras de arte en general se ha ido modificado sustancialmente, lo cual genera una nueva manera de abordar esta temática, tanto desde la teoría como desde la práctica.

En este artículo se presentan las cuestiones generales ligadas a la naturaleza fotográfica y artística en sí; tales como la relación espectador/obra, los límites entre lo público y lo privado y la mirada del espectador como un "otro" diferente al creador.
\end{abstract}

Palabras clave: autor - circulación - espectador - exhibición - Fotografía.

[Resúmenes en inglés y portugués en la página 267]

${ }^{(*)}$ Licenciada en Artes Plásticas (UBA). Fotógrafa. Ha cursado también estudios relacionados con el periodismo y crítica de arte. Docente de la Facultad de Diseño y Comunicación de la Universidad de Palermo y en otras universiades e instituciones.

\begin{abstract}
“QQué es visibilidad? Quizás la cotidianeidad de la revelación ¿Qué es entonces revelación? Que algo te ilumine con su visibilidad. ¿Cómo sucede eso? Cuando estoy al aire libre ¿Al aire libre? Cuando estoy tan afuera que el mundo se muestra" (Sloterdijk, 2007).
\end{abstract}

\title{
Introducción
}

Desde las últimas décadas del siglo XX la circulación de fotografías y de obras de arte en general se ha ido modificado sustancialmente, lo cual genera una nueva manera de abordar esta temática, tanto desde la teoría como desde la práctica. Fueron muchos los artistas y fotógrafos que quebraron los límites de la imagen logrando establecer nuevos parámetros para el arte y permitiendo el enriquecimiento de pensamientos y nuevas miradas acerca de esta experiencia social. Estos cambios en el sistema de circulación y exhibición de las fotografías en la actualidad nos conducen a reflexionar acerca de los nuevos modos de apropiación de la obra, que a su manera también repercuten en el creador. El rol del espectador es cada vez más protagónico y activo, aunque existen ciertos aspectos inherentes a la apropiación de la fotografía artística que se mantienen imperturbables. El público recibe parámetros sociales y condicionamientos psíqui- 
cos propios de su experiencia de vida que resultan contundentes por sí mismos, más allá de la forma y la velocidad en que se adquieran estas imágenes.

En este artículo presento, en una primera instancia, aquellas cuestiones generales ligadas a la naturaleza fotográfica y artística en sí; tales como la relación espectador/obra, los límites entre lo público y lo privado; y la mirada del espectador como un "otro" diferente al creador. Aspectos básicos que enriquecen el enfoque acerca de la comunicación de imágenes. A continuación me focalizo en las nuevas prácticas sociales vinculadas a lo virtual para reflexionar e indagar acerca de sus aspectos básicos y de qué manera influyen y determinan al arte y las imágenes cotidianas.

\section{Educación visual}

Para empezar, me parece fundamental referirme a la importancia de la educación visual como un camino imposible de eludir, en especial en estas últimas décadas en donde la imagen ha desarrollado un espacio en la sociedad cada vez mayor. Pensar en la forma de adquirir y comprender una imagen es el primer paso. Para esto, la alfabetización visual es un tema clave que, si bien está presente en distintos enfoques educativos desde principios del siglo XX, todavía no ha conseguido establecerse en las sociedades con la fuerza que debería.

Brindarle al espectador la mayor cantidad de herramientas posibles para que pueda desarrollar una mirada crítica y enriquecedora debería ser una prioridad absoluta entre los objetivos principales de los colegios. Dondis (Dondis, 1976) plantea que existe una sintaxis visual que debe ser enseñada a los jóvenes lo más temprano posible. Ciertos elementos que ayudan a comprender los mensajes escondidos tras las líneas, los contornos y colores. De esta manera se le brinda al principiante la posibilidad de entender que existen ciertas lecturas objetivas de una imagen, y de esta manera no caer inexorablemente en lo personal y subjetivo de quien la mira. Según esta autora, más allá de condicionamientos culturales propios del ser humano, prevalecen algunos elementos medianamente inmutables que pueden ser decodificados por quien se acerca a una imagen.

En este punto es primordial referirse a las distintas apreciaciones ligadas a lo icónico y lo simbólico. Sin caer en las grandes problemáticas referidas a este asunto, me parece pertinente mencionar algunos conceptos que trabaja Ronald Barthes en Lo obvio y lo obtuso los cuales se refieren a los dos mensajes que existen en una fotografía. Por un lado el mensaje denotado o análogo en sí, y por otro el mensaje connotado. El primero es el que se vincula directamente con la reproducción de lo real: es el análogo perfecto de la realidad; mientras que el mensaje connotado subyace en la imagen y se vincula con conceptos arraigados en lo social. "Se trata de un sentido secundario cuyo significante consiste en un determinando "tratamiento" de la imagen bajo la acción del creador y cuyo significado, estético o ideológico, remite a determinada "cultura" de la sociedad que recibe el mensaje" (Barthes, 1992, p. 13).

Para este autor es tan fuerte el sentido denotado de una foto debido a su naturaleza "imitativa", que a veces resulta difícil para el espectador arribar al otro mensaje, el connotado. Por esto propone ciertos mecanismos para reconocer los procedimientos de connotación; tales como preparar al público para descifrar los posibles mensajes ocultos tras la imagen. Lo connotado dentro de una fotografía se produce a partir del uso del trucaje, la pose, la sintaxis y otros elementos. Estos componen la imagen y le brindan al espectador la posibilidad de cerrar el 
mensaje en tono con la búsqueda del fotógrafo.

Tanto Dondis como Barthes, y otros muchos teóricos se ocupan del estudio de la recepción de las imágenes, cada uno con un enfoque diferente, abordando esta necesidad de educar al espectador para darle las herramientas necesarias a la hora de afrontar satisfactoriamente una representación. Es sabido que la alfabetización visual se adquiere en la medida en que uno se familiariza con las imágenes. Por eso, cuanta mayor sea la educación e información que brinden las sociedades a su pueblo, mayores posibilidades tendrán sus integrantes de comprender y apreciar las imágenes y sus significados. Estos y otros autores han tratado e investigado sobre las posibilidades y facilidades que se le puede brindar a un espectador con poca experiencia visual para desenvolverse con soltura frente a las imágenes. Poder disfrutar de sus formas, sus contornos y colores a la vez que logran un discurso más profundo y cercano a las intenciones del creador.

La educación visual se presenta como un aspecto latente en la sociedad que, al ir creciendo, aporta riqueza y profundidad en las imágenes y sus mensajes, tanto al creativo como al espectador. Es el costado fundamental para que todos los temas que planteo a continuación puedan tener su espacio y ser entendidos y valorados por gran parte de la comunidad.

Una buena imagen, similar al acto de lectura de un poema, posee una energía particular. Una energía intensa basada en la percepción del espectador, quien reconoce en esa imagen una comprensión de su significado, aunque percibiendo que hay algo allí que se le escapa, que lo excede. La oscilación entre conocimiento e inconsciencia se plantea como un espacio libre que surge tanto en el placer estético como en su carga simbólica. El espectador entiende la imagen, comprende su significado denotado y connotado pero también carga con una zona prohibida o un abismo inquebrantable e inconsciente. Este aspecto enterrado en las penumbras es, a mi entender, aquello que enriquece y resignifica una fotografía de autor.

Otro tema importante vinculado con la educación y circulación visual es la influencia del contexto social en la instancia de producción y recepción de imágenes. Ambos momentos se encuentran inmersos dentro de un mundo social y cultural dado de antemano. Según palabras de Vovelle (Vovelle, 1985) es imposible hacer un análisis de cualquier evento cultural sin tener en cuenta aquellos juicios y creencias compartidas por una sociedad. Desde esta óptica el arte se vincula directamente con lo social, transformando a los creadores de imágenes en mediadores que hacen circular valores y esquemas de pensamientos colectivos. Las imágenes poseen tres niveles de lectura: por un lado las vinculadas con los patrones sociales que responden a un momento histórico y geográfico concreto, por otro lado la identidad propia de ese comunicador; y por último ciertas representaciones permanentes. Estas últimas pueden ser emparentadas al concepto de inconsciente colectivo planteado por Jung (Jung, 1994) el cual es de naturaleza universal. Este autor dice que hay ciertos contenidos en las imágenes que aluden a representaciones arquetípicas en donde se hace consciente este inconsciente colectivo. De alguna manera se trata de contenidos y modos de comportamiento comunes a todos los individuos y que quedan expuestos en estas representaciones.

Una vez mencionados estos planteos sociales vinculados a la imagen podemos dar paso a otras problemáticas que son inherentes a cualquier práctica artística y su apropiación por parte del espectador. Me refiero a cuestiones que se han abierto y transformado en temas centrales dentro de la fotografía de autor contemporánea. Temas como los límites entre lo público y lo privado, el rol que ocupa el OTRO en la obra y las posibilidades infinitas que se abren en el arte con las interpretaciones abiertas que le propone el autor al espectador. 


\section{Límites entre lo público y lo privado}

Pensar en la circulación de la fotografía nos conduce inevitablemente a pensar en el avance tecnológico que se ha transformado en moneda corriente hoy en día. La gran mayoría de las personas posee una cámara digital y la posibilidad de acceder a través de la tecnología a millones de imágenes diarias. Se amplió cuantitativamente el uso de las cámaras y la creación de fotografías, así como también la adquisición de éstas a través de los fotologs y sitios que inundan el espacio virtual.

Actualmente la apreciación, el consumo y el olvido de una fotografía es una constante en nuestras vidas. La forma de adquirir cualquier concepto o sensación se traduce en un instante. Sea que una imagen conmueva, distienda o conduzca a la reflexión, todo sucede banalmente. En la superficie. Son pocas las actividades o momentos en que el medio promueve otro tipo de acercamiento más profundo y reflexivo. El mundo en su totalidad se maneja con ciertos códigos basados en lo superficial, y por ende el campo visual no escapa a estas reglas.

Podríamos pensar a la fotografía de autor como una expresión que evade estas banalidades. Son imágenes que traspasan el mundo publicitario, periodístico y cotidiano para adentrarse en conceptos y sensaciones más profundas y duraderas. En este punto, la fotografía y el arte se unen transformándose así en un solo acontecimiento que conduce al espectador a disfrutar de una compleja, rica y trascendente experiencia. Pero incluso en el arte y sus manifestaciones más comprometidas y profundas, la práctica de Internet y los blogs obligan a reflexionar acerca de la frontera entre lo público y lo privado. Hoy cada evento, cada imagen, cada acontecimiento no solo puede ser grabado en la computadora, sino también circular por la web en menos de un segundo. De esta forma todas las fotografías dejan a un lado su aspecto privado e introspectivo, para convertirse en espectáculo. Y esto incumbe por entero a la reflexión acerca de su naturaleza. Berger refiriéndose específicamente a las obras artísticas, habla de la fotografía como huella de la realidad, como un "haber estado ahí" (Berger, 2003). Su principal objetivo es ser un vestigio del pasado y despertar la memoria como un elemento vivo en nuestra conciencia. De esta manera, al transformarse en evocación y presencia, esa imagen trasciende el binomio público -privado, para convertirse en parte integrante de nuestro propio contexto. Aquel que mira, siente y reflexiona frente a una imagen, por más alejada de su realidad que sea, se la apropia para resignificarla dentro de su propio entorno. Así la experiencia personal del artista confluye en un campo sin identidad, convirtiéndose en dominio público. Quien se detiene a contemplar la obra se apropia de esa huella de la realidad que deposita el artista y la reconstruye desde sus propios conocimientos y sentimientos.

Hay muchos artistas que utilizan al arte como reflejo de su experiencia de vida, y así se cuestionan acerca de la frontera entre lo privado y el mundo exterior. Quizás, Félix González Torres sirva para pensar en estos límites. Si bien no es un fotógrafo tradicional, González Torres es un artista que utiliza la fotografía como una herramienta más en su producción. Y el tema de su vida privada aparece constantemente. Tanto su enfermedad (sida) como el amor incondicional por su pareja Ross, quien murió de ese mismo mal unos años antes que él, son prácticamente las únicas temáticas de su trabajo artístico. Un ejemplo de esto son los 24 carteles publicitarios de una foto en donde se ve una cama vacía con dos almohadas levemente ahuecadas, como si los amantes recién se hubieran levantado (1991). Esta foto hecha por González Torres apareció 
por varios días en muchas calles y estaciones de New York, haciendo alusión a la muerte de su pareja, su dolor y lo efímero de la vida.

En realidad, todos los trabajos de este artista presentan una referencia clara a su autobiografía. Cada título de sus obras mencionan algún acontecimiento placentero: una comida, un paseo o cualquier suceso que evoque el amor hacia su pareja. $\mathrm{O}$, en la vereda opuesta, simplemente obras que hablan del dolor por la pérdida de su novio Ross; como por ejemplo los rompecabezas hechos a partir de fotografías privadas del artista y las cartas de amor enviadas entre él y su amante. Por otro lado, también otros trabajos hacen alusión al sida y sus sufrimientos, tal como la cortina de luces titulada Quimio. Ahí el artista denuncia su propia tristeza que lo desborda mientras lleva adelante la serie de quimioterapias que debía hacerse por su enfermedad. La obra es una cortina de cuentas de collares que representaban los glóbulos blancos que perdía día a día. En la obra titulada Placebo, González Torres vuelve a referirse a su enfermedad, pero esta vez aludiendo al engaño del sistema hospitalario: esos medicamentos que solo funcionaban como promesa de una cura, sostenidos por el poder de la fe y las ganas de creer en una mejoría. Placebo es una torre de caramelos, las cuales se encuentran abiertas al público. Cada espectador puede tomar un dulce, llevarlo a la boca y reflexionar acerca del daño mental que puede producir la ilusión engañosa, la promesa incumplida.

Todas estas referencias nos muestran la clara necesidad del artista por hacer visible su propia experiencia de vida. Esta tendencia, que se acrecienta cada vez más en los artistas contemporáneos, impide un límite claro entre lo público y lo privado, dejando a la vista un mundo que se disuelve entre la multitud de espectadores. Y esta barrera débil y desdibujada ha traspasado los límites de lo artístico y se ha instalado en el mundo cotidiano de las imágenes. Como mencionamos anteriormente cada página en Internet, facebook o fotolog se nutre y se enriquece con fotografías personales. Fotos para el uso interno se transforman en eslabones de una cadena de comportamientos sociales que desenmascaran a gritos la vida privada.

Hoy los espacios se han superpuesto a tal nivel que no existe una frontera clara entre público y privado. Este concepto dualista vinculado a la imagen ha quedado enterrado como una práctica más que se ha perdido en este nuevo milenio.

Los trabajos artísticos del tipo de González Torres son una manera de imponer la intimidad. Es una concepción del yo que se muestra como una figura abierta y pública, la cual interactúa con el otro a partir de vínculos dinámicos y flexibles. No es la pertenencia a un grupo lo que brinda la identidad sino la exposición y el intercambio continuo. Usando el término utilizado por Michel Maffesoli (Maffesoli, 2001) lo que se trata no es de un mundo fragmentario, sino de relaciones marcadas por lo "impermanente": nuevos modos y vínculos que se reescriben constantemente en un fluir relajado y poco estructurado. De esta forma nos enfrentamos a un enfoque basado en personajes que construyen su identidad a partir de la exposición y la construcción de sus propias experiencias de vida. Arte y cotidianeidad se unen: tanto los artistas como cualquier persona que escribe en los blogs o cuelga fotos en los fotologs introducen una forma de comunicación entroncada en la exhibición sistemática de la intimidad.

De modo que, si bien es cierto que la apropiación de las imágenes a partir de esta identidad fragmentada que anula el binomio público y privado ha establecido nuevos parámetros en la recepción y significación de las imágenes, también existen otros aspectos que movilizan al espectador en su interior, más allá de los cambios dados en la creación y la circulación de las obras. 


\section{Espectador / obra}

El mundo de las imágenes, cada vez más apabullante, nos conduce a pensar en el espectador y sus maneras de apropiarse de las representaciones. La fotografía de autor hoy nos conduce a un tipo de espectador amplio, capaz de decodificar mensajes y transformarlos según sus propias vivencias y experiencias.

Según este punto de vista, Umberto Eco propone que el espectador, de acuerdo a sus propias características psicológicas y su propia historia y cultura, se apodera del contenido de una obra en busca de un significado personal y subjetivo. De modo que se estimula la libre interpretación y apertura de significados. Cada día con más fuerza la idea de la no conclusión está presente en los artistas, permitiendo al público que terminen la obra de acuerdo a su propia visión del mundo. Este enfoque planteado por Eco se vincula con la idea de relatividad, en donde no existe una verdad absoluta. Se quiebra la relación obra / consumidor, superando de esta forma el binomio presentación / contemplación, tan presente en la historia del arte desde los comienzos (Eco, 1985). Otra vez González Torres nos sirve como ejemplo de este sistema comunicativo, en donde la experiencia del espectador cobra una importancia inusitada y transgrede lo ya establecido. En sus exposiciones este artista invitaba al público a tocar y apropiarse de la obra de arte. Una de sus instalaciones consistía en hojas de papel apiladas a diferentes alturas. Su número era ilimitado, para que se pudieran reemplazar, y tenían impresos textos e imágenes inquietantes o equívocos. Los asistentes podían llevarse una o más hojas con ellos porque justamente el artista perseguía la interacción con el público. Sin este contacto Félix González Torres sentía que sus obras no tenían sentido. Otra instalación de este tipo son las ya mencionadas torres de caramelos (Placebo) esparcidos por el suelo de la galería, o amontonados en los rincones, los cuales eran ofrecidos para ser consumidos por los visitantes.

De esta manera el artista muestra la idea de constante fluctuación de la obra y lo efímero de las cosas. A la vez, este gesto de generosidad nos habla de aprender a dejar ir. Su propia obra se desvanece con el correr del tiempo, y para él esto señala su propio existir:

Yo estaba perdiendo a Ross, de modo que quise perderlo todo para enfrentarme con ese miedo y quizás aprender algo de él. Así que quise perder también la obra, eso que era tan importante en mi vida. Quería aprender a dejarla ir (AA. VV., Catálogo MALBA, 2008, p. 34).

Los vínculos entre el público y el creador aparecen reflejados en distintos puntos y desde diferentes enfoques. Una de ellas es la propuesta de Barthes en donde proclama dos conceptos fundamentales a la hora de abordar una fotografía: el studium y el punctum (Barthes, 1997). El primero es la manera en que percibo sin una agudeza especial aquello que el fotógrafo quiere mostrarme o decirme, mientras que el punctum es “(...) lo que viene a perturbar al Studium (...) El punctum de una foto es ese azar que en ella me despunta (pero que también me lastima, me punza)" (Barthes, 1997, p. 65).

Este binomio permite entender a la imagen como un cúmulo de cultura, historia y pasado que se entrecruzan con el espectador. A través de este punctum, Barthes verbaliza ese lugar de encuentro en donde la historia del otro y su visión se convierten en propia. Es donde el abismo de dos individuos aislados y subjetivos puede desaparecer en pos de un espacio en común. En 
definitiva, Barthes plantea que el punctum es lo que nos permite a nosotros espectadores fusionarnos, aunque sea por un instante, con aquello que vivió el autor y desembocó en la imagen. Definitivamente este concepto de Barthes ayuda a poner en palabras un sentimiento inexplicable que se abre camino cuando una imagen queda exhibida, tanto en un fotolog como en una galería de arte. A través del punctum el autor presenta esa herida que se abre y nos transporta a un nuevo espacio, repleto de ideas y preconceptos que tambalean. Una obra de arte, lejos de perder el aura (Walter Benjamin, 1935) gana, gracias a la posibilidad de reproducirse y circular por el mundo indiscriminadamente.

\section{El otro y lo diferente}

El problema del otro, de un alter ego que observa y disiente acerca de lo que ve, es una cuestión muy importante a la hora de abordar cualquier estudio sobre la recepción y comunicación de una imagen. La alteridad como vínculo entre el espectador y el creador de una fotografía resulta un tema polémico que debe ser abordado para enriquecer esta temática. El otro siempre difiere, de algún modo, con quien se enfrenta. Tal como lo entiende Victor Segalen en su estudio sobre el exotismo, el otro siempre será un misterio, un ser con el cual en algún punto no me comunico; y que debe ser entendido así (Segalen, 1989). Un espacio vacío se abre entre autor/espectador que provoca confusión, pero también riqueza. Es por eso que muchos artistas vuelcan su producción y reflexión hacia esta temática. Sophie Calle, una artista francesa contemporánea que se describe a sí misma como fotógrafa y escritora, prioriza en sus trabajos la mirada hacia el otro. Constantemente su producción se enfrenta al otro como un ser diferente y enigmático. Busca comprenderlo, entrar en su intimidad y robarle su mirada. Un ejemplo de esto es su insólita persecución a un extraño por la calles de París, documentando cada uno de sus movimientos. En otra ocasión entró a trabajar como mucama de un hotel para poder fotografiar las pertenencias de los huéspedes. De alguna manera, Sophie Calle intenta entender el espíritu profundo del "otro", de ese ser discontinuo a su propia existencia. El abismo que se abre entre el yo y el otro se transforma para la artista en material indispensable, casi único y fundamental, para su tarea. "Dolor exquisito" es otro de sus trabajos que trata sobre el dolor propio y ajeno. A raíz de una historia de amor frustrada que vivió la artista en un viaje a Japón, nace esta muestra dividida en dos partes, una basada en sus propias vivencias sobre este viaje, y la segunda es la narración de otras experiencias sentimentales vividas por sus amigos. Según ella misma cuenta, al terminar este trabajo, y después de embeberse del sufrimiento ajeno, pudo dar vuelta la página de su propia historia. Como si entender y acercarse al otro fuera el remedio de sus propios males. Gran parte de su trabajo consiste en intentar derrumbar las fronteras inquebrantables entre ella y su prójimo. Y ese prójimo también es el espectador.

Aunque ella no lo especifique, al intentar adentrarse en el otro, que puede ser un extraño por la calle, o a partir de las historias de amor narradas por un amigo, la artista se está refiriendo a todo espectador que se interese en su obra. El abismo al cual se enfrenta es un desafío constante. Otro trabajo de Sophie Calle que se enmarca dentro de esta problemática es "Les Dourmeurs" ("Los durmientes") de 1979, un proyecto en donde la artista invita a extraños que conocía casualmente, sean mujeres o varones, a que durmieran algunas horas en su cama. Juntaba a dos personajes que no se conocían entre sí y los hacía dormir juntos, compartir la cama y el sueño. 
Mientras tanto Calle los filmaba y fotografiaba, cual científica conduciendo un experimento.

Lo que me gustaba era tener en mi cama gente que no conocía, de la calle, que no sabía lo que hacían, pero que a mi me daban su parte más íntima, (...) ver como dormían ocho horas por la noche, como se movían, si hablaban, sonreían. Esta gente no sabía quién era ni qué hacía... (Siganevich, 2009).

Se trataba de un laboratorio en el cual se enfrentaban opuestos: objetividad vs. afecto, anonimato vs intimidad.

En definitiva su trabajo apuntaba a reconocer al otro, a despertar del letargo de la indiferencia de cada uno de los seres humanos frente al diferente. De alguna manera proponía con su performance romper momentáneamente el abismo que existe entre los individuos. Ese abismo que Bataille plantea como punto indiscutible de la naturaleza humana y que solo puede reubicarse a través del erotismo y la muerte (Battaille, 2006). Sophie Calle le responde a este autor proponiendo una forma de conexión entre "otros" dada por la intimidad y el sueño.

Por otra parte, debemos pensar en el espectador: ¿qué lugar ocupa en estos cuestionamientos? Lo más probable es que se ubique al margen del vínculo entre esos dos desconocidos y de la relación de la artista con estos extraños. Entonces su espacio se transforma en el OTRO por excelencia. Un ser que desde el anonimato absoluto, espacial y temporalmente, atraviesa la experiencia de la artista y sus modelos, con sus propias vivencias y su bagaje psicológico y social. Aparece como una alteridad absoluta enfrentada a toda la situación concreta de la performance. Estos tipos de experiencias se repiten en mayor o menor medida en las producciones artísticas de las últimas décadas del siglo XX y que subsisten con mucha fuerza en estos primeros años del XXI.

\section{Exhibición y producción masiva}

En definitiva, hoy en día nos enfrentamos con una realidad que circula en el mundo artístico y cotidiano: todo es fotografiable. Todo asume el rango de objeto a fotografiar. La realidad es que hasta hace algunas décadas existían estatutos y géneros claramente establecidos, los cuales actuaban como parámetros sociales acerca de lo que debía perdurar en el tiempo. Fotógrafo, artista o amateur sabía y tenía claro cuáles eran los objetos fotografiables y cuáles no.

Hoy todo vale. Desde una silla vacía, un cenicero, un perchero o la comida del domingo en familia. Cada escena, cada objeto, posee una importancia tanto para el creador como para el espectador que les permite dedicarle tiempo y atención a estas cuestiones mal llamadas "efímeras". En cada instante se abre el mundo entero, un zapato puede sostener el accionar y la historia de toda la humanidad. Sean objetos, sean miradas y retratos, todo porta lo universal en su interior. Un descubrimiento que comienza con el artista y se expande en la sociedad entera. Frente a este enfoque es posible determinar que existe una mirada niveladora y democrática, la cual colabora a poner en duda qué es importante y que no. A la manera de los artefactos duchampianos, las imágenes recorren su propio camino, encontrando huecos y senderos alternativos que permiten nuevas estéticas.

Hay muchos ejemplos que demuestran esto a lo largo de las últimas décadas del siglo XX, y que se asientan en la comunidad como una verdad irrefutable, especialmente en los comienzos 
del siglo XXI. Nan Goldin, Richard Billingham y tantos otros resultan ser pioneros de esta capacidad del ser humano por quebrar el límite impuesto para el arte, en donde la belleza o la denuncia de conceptos universales, son su única verdad. Artistas que mediante sus fotografías han creado puentes y establecido otras verdades.

Richard Billingham es un fotógrafo inglés conocido en la década de los '90 por los retratos orientados hacia su propia cotidianeidad. Sus fotografías evocan la vida familiar de sus afectos más cercanos, en particular su padre con quien tenía una relación muy particular. El artista realizaba tal cantidad de fotografías que sus familiares se olvidaban de la presencia de la cámara, lo que ayudaba a reflejar con naturalidad el día a día de su hogar. Sus imágenes no respetan la belleza ni la calidad técnica. Se trata de un realismo crítico basado en el ámbito de su privacidad como material de creación. Todos los personajes retratados, junto con la constante presencia de perros y gatos que también formaban parte del entorno familiar, dejan a la vista un álbum bizarro, crudo y auténtico. Fotografías sinceras que transforman en explícito lo íntimo, colocando a los retratados en un espacio de tremenda vulnerabilidad.

Otro ejemplo paradigmático de este tipo de fotografías, en donde la técnica y la belleza pasan a segundo plano es Nan Goldin, fotógrafa norteamericana quien es conocida por retratar la atmósfera de lo cotidiano en compañía de sus amigos. Cada imagen es un instante de su entorno y sus afectos. Cada foto representa su propia vida. $\mathrm{Y}$ a la vez es un documento histórico que reproduce la contracultura neoyorkina de la década del '70 y ' 80 . En cada foto cuenta de una manera cruda, frontal y sin belleza los sinsabores de esta realidad.

Cuando pensamos en las prácticas sociales vinculadas con la circulación de imágenes hay otros asuntos involucrados. Concretamente estoy hablando de los museos y galerías como espacios de poder y hegemonía. Es claro que estos lugares existen y se desarrollan como "instituciones modernas", cuyo principal objetivo es hacer visible la producción de los artistas. En los últimos años del siglo XX se ha dado un alto crecimiento de producción y también una inflación de lo exponible, lo cual desemboca en un aumento exponencial de estos espacios del arte. Ferias, exposiciones y galerías organizan y le brindan a la obra nuevas lecturas, ajenas al creador y sus intenciones. El arte posee hoy una característica fundamental: su forma abierta y pública. Esto se debe tanto por la mano del que lo hizo, o del curador y crítico que utilizan las imágenes para armar nuevos discursos.

Este aumento de producción de imágenes y de visibilidad de las mismas como objetos exponibles y artísticos, se combina con el crecimiento inusitado de las tecnologías y las comunicaciones en red. En el siglo XXI, en plena era digital, se genera un movimiento descentralizador de quienes portan la última palabra acerca de lo que es arte y de lo que debe exponerse y lo que no. Hoy el museo es, según palabras de Vásquez Rocca objeto de una desterritorialización debido a la aparición y crecimiento abrumador de las galerías virtuales, quienes son ahora el punto de contacto entre creador, obra y espectador (Vásquez Rocca, 2008). El arte puede estar en todas partes a la vez, ya no hay más centro y periferia y el poder de las instituciones va desapareciendo lentamente dejando el espacio a otra forma de pensar el mundo, más democrático y globalizador. La tecnología nos cambia y nos demuestra que tiene mucho para enseñarnos. Desplaza el rol hegemónico de algunas instituciones y despierta otras maneras de circular.

Dentro de las prácticas artísticas actuales vemos nuevas formas de plantear la obra, desde creaciones compartidas, autorías grupales, etc. No solamente el consumo se transforma y resignifica, acercándose a un sistema más libre, sino que también la creación marca diferencias 
con la era analógica a partir de las infinitas posibilidades que se abren en el camino. Según lo planteado por Margarita Schultz podemos pensar en el ciberespacio a partir de tres conceptos básicos: interacción, colaboración y distribución (Margarita Schultz). Las distintas rutas dentro de Internet, su información diversa y la gran capacidad de comunicación que despierta en la sociedad, ha generado nuevas formas básicas de relación. Su mayor característica es la colaboración entre individuos lejanos en tiempo y espacio; la idea de que se puede trabajar en conjunto sin depender de una coordinación en tiempo ni lugar. Creación conjunta y apropiación de imágenes virtuales sin límites espaciales ni temporales es un potencial que crece cada día más.

\section{Conclusiones}

Frente a todo lo planteado hasta aquí, ¿Podemos pensar que la circulación y exhibición de las fotografías ha cambiado sustancialmente en igual medida que su soporte? Hoy la pantalla de la computadora se transformó en el soporte por excelencia. Las imágenes están deambulando en el ciberespacio, virtualmente presentes a la manera de los recuerdos que cada uno puede evocar en su mente. El espectador sabe que eso que está enfrente es una imagen - fantasma, construida mediante pixeles. En este espacio la realidad se conjuga con la ficción, como en una fórmula casi mágica. Se logra una apertura comunicativa a distancia, permitiendo disfrutar, sufrir y contemplar todo tipo de imágenes, de diversos lugares y culturas, con gran facilidad de acceso. Como decíamos anteriormente, tiempo y distancia ya no actúan como limitaciones. Una nueva ola de circulación de imágenes se está llevando a cabo frente a nuestras propias narices. Una nueva forma de apropiación y también de producción. Pero por otro lado es cierto que hay ciertas características del ser humano que no mutan. Ciertas cuestiones propias en el vínculo creador/espectador que traspasan la frontera de la mirada, y se instalan como problemáticas vinculadas con lo filosófico y lo humano.

La construcción de un discurso único de la verdad del arte está en plena decadencia. El descentramiento de la circulación de imágenes, en donde el museo y las galerías de arte han perdido su espacio consagratorio, nos muestra claramente que el arte y sus imágenes no pueden ser fijas ni inmóviles. El museo como centro de operaciones está inmerso dentro de un contexto social y un momento histórico determinado. Y como tal, no está ajeno a las transformaciones tecnológicas y sociales que se viven en la actualidad ni a los distintos modos de producción artística derivados de dichas transformaciones. Aparecen nuevas prácticas virtuales que generan nuevos modos de comunicación entre los ciudadanos. Y esto, despierta la resignificación de la lógica discursiva latente hasta hoy. El museo y las galerías han perdido espacio debido a que el arte puede estar hoy en todas partes a la vez, puede reproducirse hasta el cansancio sin perder un gramo de su naturaleza.

La digitalización y el mundo tecnológico configuran otra forma de traducir los conocimientos en una nueva comunidad virtual sin centro ni periferia. El intercambio y circulación, tanto textual como visual, genera un tráfico de saberes insospechados hasta hoy. Se crea un diálogo abierto y dinámico que permite la plena "aprehensión del sentido", vinculado con el acto de ver y conocer, lo cual favorece a la creación de comunidades. Esta práctica en la esfera pública termina generando vínculos sociales infinitos, basados en los efectos de identificación y reconocimiento de las partes. También esta circulación masiva de fotografías e imágenes aporta 
una nueva forma de acercarse a la obra de arte, tan lejana ahora de lo "aurático" (y su pérdida denunciada por Walter Benjamín en 1935) hacia un lugar democrático y ubicuo.

La esencia de las imágenes digitales no se vincula con proclamar la eternidad de lo inmóvil (tal cual concebimos las representaciones analógicas) sino que el camino por lo real es efímero, en un constante "estar" pero a la vez un permanente "dejar de estar". Es un paso por lo fugaz y volátil, basado en la idea de flotación. La promesa de una imagen eterna y perdurable frente a lo efímero de la vida se quiebra, permitiendo la entrada de otra lógica ligada a lo virtual. Ya no hay materia, solo las representaciones que emergen de la computadora.

Entonces, ¿cómo se puede pensar la fotografía en este mundo contemporáneo basado en lo inmaterial? ¿Nos enfrentamos a una nueva cultura visual? ¿O la imagen virtual surge de la misma lógica de la plástica y la fotografía? ¿No parten acaso todos de la misma mano como construcciones ficcionales a las que ingresamos visual y mentalmente?

¿Hay una mayor apropiación de la imagen a partir de la fluidez en las comunicaciones virtuales? ¿El campo de las artes está mutando hacia nuevos paradigmas? La multiplicación constante de fotografías en la web ¿está fagocitando nuestro interés y nuestra capacidad de reflexión? ¿Estamos acercándonos a una nueva era donde la superficie y la cantidad consumen toda la atención? ¿Cuál es nuestro límite?

Son muchas las preguntas. Hoy, los pensamientos tienden a la fluidez, a romper con las estructuras del pasado, pero sin retornar al orden y a una única verdad. Hoy, nos enfrentamos con otras posibilidades de apropiación de la realidad, lejos ya de las murallas cerradas y estancadas de otras épocas. Hoy, podemos hablar de un proceso que recién comienza. A cada paso se nos van abriendo nuevas puertas y caminos. Artistas, críticos y espectadores vamos transitando por senderos apenas iluminados. De vez en cuando, alguna luz se enciende, algún concepto u obra despierta reflexiones y otras posibilidades aparecen. Y así se va reformulando la esencia de nuestra realidad fotográfica.

El humilde objetivo de este artículo es disparar nuevas preguntas y cuestionamientos que puedan ser parte de una búsqueda profunda acerca de la naturaleza de la fotografía digital y su forma de apropiación. Se trata de una práctica que se está despertando y creciendo a pasos agigantados en las últimas décadas. Muchos creen que la fotografía analógica ya ha desaparecido frente a lo digital. También muchos vaticinaron en el siglo XIX la muerte de la pintura cuando se descubrió la fotografía. Pero nada de eso ha sucedido, la historia demuestra que los conceptos se encabalgan unos sobre otros y que la coexistencia es posible, permitiendo que nuestras artes y expresiones se enriquezcan y convivan en armonía.

\section{Lista de Referencias Bibliográficas}

AA.VV. (2008). Félix González Torres Somewhere/Nowhere Algún lugar/Ningún lugar. Buenos Aires: Malba.

Barthes, R. (1997). La cámara lúcida. Barcelona: Editorial Paidós.

(1992 2a Ed). Lo obvio y lo obtuso. Imágenes, gestos, voces. Barcelona: Editorial Paidós.

Battaille, G. (2006). El erotismo. Buenos Aires: Editorial Tusquets.

Benjamin, W. (1935). "La obra del arte en la época de la reproductibilidad técnica", en Discursos Interrumpidos I. Madrid: Taurus. 
Berger, J. (2003). Mirar. Barcelona: Editorial Gili.

Dondis, D. (1976). La sintaxis de la imagen Introducción al alfabeto visual. Barelona: Editorial Gustavo Gili.

Eco, H. (1985). “La obra abierta” en La definición del arte. Barcelona: Editorial Planeta. Jung. C.G. (1994). Arquetipos e inconsciente colectivo. Buenos Aires: Editorial Paidós.

Maffesoli, M. (2001). El instante eterno. El retorno de lo trágico en las sociedades posmodernas. Buenos Aires: Paidós.

Segalen, V. (1989). Ensayo sobre el exotismo. México: FCE.

Vásquez Rocca, A. (2008). "Estética de la virtualidad y deconstrucción del museo como proyecto ilustrado" en Revista Nómadas No 28. Colombia: Facultad de Ciencias Sociales, Humanidades y Arte, Universidad Central.

Vovelle, M. (1985). Ideología y Mentalidades. Barcelona: Ariel.

\section{Bibliografía}

AA.VV. (2008). Félix González Torres Somewhere/Nowhere Algún lugar/Ningún lugar. Buenos Aires: Malba.

Barthes, R. (1997). La cámara lúcida. Barcelona: Editorial Paidós.

(1992 2a Ed). Lo obvio y lo obtuso. Imágenes, gestos, voces. Barcelona: Editorial Paidós.

Battaille, G. (2006). El erotismo. Buenos Aires: Editorial Tusquets.

Benjamin, W. (1935). La obra del arte en la época de la reproductibilidad técnica, en Discursos Interrumpidos I. Madrid: Taurus.

Berger, J. (2003). Mirar. Barcelona: Editorial Gili.

Dondis, D. (1976). La sintaxis de la imagen Introducción al alfabeto visual. Barelona: Editorial Gustavo Gili.

Eco, H. (1985). La obra abierta en La definición del arte. Barcelona: Editorial Planeta.

Goldin, N. (1986). La balada de la dependencia sexual. Nueva York: Aperture Foundation, Inc. Jung. C.G. (1994). Arquetipos e inconsciente colectivo. Buenos Aires: Editorial Paidós.

Krauss, R. (1985). La originalidad de la vanguardia y otros mitos modernos. Madrid: Editorial Alianza.

Marchan, S. (comp.) (2006). Real/virtual en la estética y teoría de las artes. Barcelona: Paidós.

Maffesoli, M. (2001). El instante eterno. El retorno de lo trágico en las sociedades posmodernas. Buenos Aires: Paidós.

Segalen, V. (1989). Ensayo sobre el exotismo. México: FCE.

Sontag, S. (2006). Sobre la fotografía. Buenos Aires: Editorial Alfaguara.

Sougez, M. L. (1996). Historia de la fotografía. Madrid: Editorial Cátedra.

Schultz, M. (1998). La Estética y el soporte digital: estética e informática en La Ferla, J. (comp). Arte Audiovisual: tecnologías y discursos. Buenos Aires: Eudeba.

Vásquez Rocca, A. (2008). Estética de la virtualidad y deconstrucción del museo como proyecto ilustrado en Revista Nómadas No 28. Colombia: Facultad de Ciencias Sociales, Humanidades y Arte, Universidad Central.

Vovelle, M. (1985). Ideología y Mentalidades. Barcelona: Ariel. 


\section{Recursos Electrónicos}

Brea, J. L. (2007). Cambio de régimen escópico: del inconsciente óptico a la e-image en Estudios Visuales. Disponible en: http://www.estudiosvisuales.net/revista/pdf/num4/JlBrea-4-com pleto.pdf

Schultz, M. El Concepto de Arte Colaborativo Facultad de Artes Universidad de Chile. Disponible en http://www.martagonzalezobras.com.ar/concepto.html. Recuperado día 25/02/2010.

Siganevich, P. (2009). SOPHIE CALLE entre cuatro paredes en Revista Salagrumo. Disponible en: www.salagrumo.org. Recuperado día 20/03/2010.

Sloterdijk, P. (2002). El arte se repliega en sí mismo. Disponible en: http://www.brumaria.net/ textos/petersloterdijk.htm. Recuperado día 20/02/2010.

Summary: From the last decades of Xxth century the circulation of photographies and art works has been modified substantially, generating a new way to approach this thematic as much from the theory as from the practice. This article presents those thematics linked to the photography nature; such as the audience-work relationship, the bonds between public and private and the glance of the audience like "an another" different from the creator.

Key words: author - audience - circulation - exhibition - Photography.

Resumo: Desde as últmas décadas do século XX a circulação de fotografias e de obras de arte en geral foi-se mudando sustancialmente, gerando uma nova maneira de abordagem desta temática, tanto desde a teoria como desde a prática.

Neste artigo se apresentam as questões gerales ligadas à natureza fotográfica e artística, tais como a relação espectador/obra, os limites entre o público e o privado e a mirada do espectador como um "outro" diferente ao criador.

Palavras chave: autor - circulação - espectador - exibição - Fotografia. 